Magdalena Koźluk (Łódź)

(iD) https://orcid.org/0000-0001-7775-3594

\title{
ReAding AND ANNOtATINg GALEN BETWEen 1515-1531: ON SOME LATIN GALEN EDITIONS IN THE LIBRARY of The Carmelites in Cracow
}

\footnotetext{
$\mathrm{R}$
} ead with piety in Western Europe, and as much by great doctors as by minor esculapes, Galen also knew his fortune in Eastern Europe. The purpose of our paper is to expand the territory of the reception of the master of Pergamum and to see how Galen was read and annotated in the period of interest from a little known corpus, that of the copies of works of Galen preserved in the library of the Carmelite convent of Cracow ${ }^{1}$.

Among all the valuable books that this library holds, we find among others an Articella of Venice from $1507^{2}$ (including Liber Techni by Galen) and one edition of Galen - the edition of Venice $(1531)^{3}$. In order to arouse the interest of the

\footnotetext{
${ }^{1}$ The Library of the Carmelite Convent in Cracow (Karmelicka Street 19) offers an incredible opportunity not only for a book historian but also for a medical historian. Located in the Piasek district, within the convent itself, this library contains about twelve thousand antique prints. Of all the collections in the convent, that of the Swiss doctor, Anton Schneeberger (1530-1581), has already been the first approach of our part during the Journées d'histoire de la Médecine in Tours organized by the French Society for the History of Medicine (18-20 May 2012). See M. KoźLuK, S. SuŁECKI, Une petite perle de Cracovie: la bibliothèque médicale d'Anton Scherberger (1530-1581), HSM 46, 4, 2012, p. 441-452.

${ }^{2}$ Articella, Venetiis: per Petrum Bergomensem de Quarengiis, 1507. (In hoc volumine parvo in quantitate, maximo in virtute continentur infrascripti codices. Liber hysagoge Joannitii. Liber Phylareti de pulsibus. Liber Theophili de urinis. Jusjurandum Hypocratis. Liber pronosticorum Hypocratis. Liber aphorismorum Hypocratis secundum antiquam translationem et novam pariter Theodori Gaze elegantissimam. Collectio aphorismorum Hypocratis ad unamquamque egritudinem pertinentium. Liber aphorismorum Damasceni. Flosculi in medicina ex Cor. Cel.extracti. Liber techni Galeni secundum antiquam translationem et novam pariter elegantissimam. Textus duarum primarum fen primi Avicenne in theorica. Textus fen quarte primi, et prime quarti in practica. Cantica Avicenne. Textus noni Almansoris de egritudinibus a capite usque ad pedes. Collecta Jacobi de Partibus in medicina pro anthomia). See J.R. Durling, A Chronological Census of Renaissance Editions and Translations of Galen, JWCI 24, 3/4, 1961, p. 251.

${ }^{3}$ Claudii Galeni Pergameni, medicorum, post Hippocratem principis, haec opera, vol. V, Venetiis: in aedibus Lucaeantonii Iuntae Florentini, 1531. On Giuntine edition between 1528-1533 see S. ForTUNA, Galeno a Sarnano: le Giuntine del 1531 e del 1533, IMU 37, 1994, p. 241-250.
} 
researchers for these copies of Galen's works, we intend above all to shed some light on their annotations and to sketch the phenomenon of scholarly reading in the first half of the sixteenth century, distinguishing between at least some of the types of annotations found in the copies concerned ${ }^{4}$. We will try to see how the educated reader of the time read Galen, by what intellectual paths he apprehended classical medicine and which passages of the Galenic corpus particularly attracted his attention.

\section{Emphasizing and commenting at the margin}

Let's start with the first copy, a composite volume made of two pieces: the Venetian edition of an Articella (1507) a little enlarged because it contains more treatises than the Articella canonical ${ }^{5}$ and Carmina urinarum iudiciis (Lyon, 1505) ${ }^{6}$.

The entire volume is richly annotated. We are particularly interested in the multiple annotations found in the copy of the Liber Techni by Galen (Ars medicinalis). Let's look at them closely because we have a first category of annotations. In the 'tertia p [ar] libri I. Tegni Ga. [leni] corpore', the annotator highlights the sentence and adds in the margin his comment which is unfortunately difficult to read. On the other hand, the sentence underlined in the text concerns the definition of the healthy body according to Galen: 'propriam ipsius sani corporis essentiam' [...] 'ipsius propriam sani corporis qualitatem' (picture 1).

In order to put this annotation in the context of Galen's thought, note that it is in the Ars medicinalis where Galen ${ }^{7}$ is dealing with the nature of the bodies (healthy, sick, neutral), explains how to understand, according to him, the nature of the healthy body ${ }^{8}$. Let us just recall in this connection that the teacher of Pergamum distinguished in the nature of the healthy body two possibilities: the state

\footnotetext{
${ }^{4}$ J.-M. Chatelain, Humanisme et culture de la note, RBNF 2, 1999, p. 26-36.

${ }^{5}$ As we see in the transcription of the title page, this volume consists in fact of treatises traditionally integrated into the canonical Articella (Johannitius' Isagoge, Filaret's De pulsibus, Theophile's Urinis, Prognosis of Hippocrates, Aphorisms of Hippocrates (seven books translated by Theodore of Gaza), aphorisms drawn from Hippocrates concerning acute diseases (Collectio aphorismorum Hypocratis ad unamquamque egritudinem pertinentium) - note that in the canonical Articella there is also the whole of the treatise of Regime of the acute diseases). Our copy also includes other titles, namely: the aphorisms of Jean de Damascene, the Flosculi of Celse, the Liber Techni of Galen, the Ars parua of Galen, the Liber Canonis Aboali Albinscei, Cantica Avicennae, the Nonus almansoris of Rhazes, Summula Jacobi de Partibus collecta in medicina pro anthomia.

${ }^{6}$ Carmina de urinarum iudicijs: edita ab excellentissimo domino magistro Egidio cum expositione et commento magistri Gentilis de fulgineo noviter castigatis et pluribus in locis emendatis per magistrum Avenantium de camerino artium et medicine professorem, Lugduni: per Franciscum Fradin, 1505.

${ }^{7}$ For the French translation of Ars Medicinalis fragments, see Veronique Boudon's translation of her critical edition of Galen. See Galen, vol. II, Exhortation à la médecine. Art médical, trans. et ed. V. Boudon, Paris 2000 (cetera: GALen).

${ }^{8}$ GALEN, p. 278.
} 
of health present ('eo tempore') and the state of health given once and for all from birth ('quidem is semper'). We may be mistaken, but we think that this fragment attracted our annotator not only because of the definition of the dual nature of health, but primarily because of the two notions used, namely the 'essentia' and the 'qualitas', which refer in the original text to those of 'eukrasia' (well-balanced temperature, good temperature) and 'symmetria' (correct proportion) - two basic notions for the definition of health in the galenic thought.

Our annotator has marked this place not without a cause. Our translation is that of Gerald of Cremona and of Laurentinus Laurentianus (Venice, 1506, as is often the case, this copy bares the alternative date of 1507$)^{10}$. It is therefore the first translation of the Ars medicinalis into Latin. In all probability our annotator who lived later, was acquainted with other Latin versions of the Ars medicinalis ${ }^{11}$, as for instance the Latin translation of the Ars medicinalis by Nicolao Leoniceno edited by Rabelais in Lyon (Gryphius, 1532, p. 277) ${ }^{12}$, where the translator proposes the notion of 'bona temperatura' for 'eukrasia' and the notion of 'commoderatio' for 'symmetria', with their Greek equivalents marked by an asterisk at the margin. In all probability, our annotator underlined the discrepancy between the translations he knew, a divergence which testifies inter alia to the perplexity of the first translator (Gerald of Cremona and Laurentinus Laurentianus) and of the others when faced with translating the concepts of 'eukrasia' and 'symmetria'.

Let's summarize. This peculiarity, apparently of a stylistic nature, reflects at bottom a great embarrassment of the time, that of a nomenclature in the making and, more precisely, that of the precise application of the medical lexicon. Much has already been said and written about the strategies of translating medical literature and the linguistic problems faced by translators when the doctrines of the ancients moved from the original cultural and linguistic milieu to the new one that collected them - transmission. Medical knowledge from Greek to Arabic, from Greek to Latin ${ }^{13}$, and from Latin to vernacular languages. But whatever the language,

\footnotetext{
${ }^{9}$ For the explanation of this fragment of Galen's text we refer to Galen, p. 398-399, note 1.

${ }^{10}$ See J.R. Durling, A Chronological Census..., p. 251. We shall not consider here the issue of the identity of the translator (Bartholomaeus of Salerno or an anonymous translator in southern Italy ca. 1150). On this readers should refer to V. Boudon, La translation antiqua de l'Art médical de Galien, [in:] Storia e ecdotica dei testi medici greci, ed. A. Garzyna, J. Jouanna, Napoli 1995, p. 43-55 and to her edition of the Ars medica de Galien, Paris 2000, p. 244-252; N. Palmieri, Sur les traces d'une ancienne traduction latine de l'Ars medica, L 56, 1977, p. 504-533; F. WALLIS, $13^{\text {th }}$ Century Commentaries on the Tegni: Bartholomaeus of Salerno and Others, [in:] L'Ars Medica (Tegni) de Galien. Lectures antiques et médiévales, ed. N. PALmieri, Saint-Étienne 2008, p. 127-168.

${ }^{11}$ See S. Fortuna, The Latin Editions of Galen's 'Opera omnia' (1490-1625) and their Prefaces, ESM 17, 2012, p. 391-412.

${ }^{12}$ Ars medicinalis, [in:] Hippocrates, Hippocratis ac Galeni libri aliquot, ed. F. Rabelais, Lyons: S. Gryphius, 1532-1533 (see J.R. Durling, A Chronological Census..., p. 257).

${ }^{13}$ Let's just quote R. French, Ancients and Moderns in the Medical Sciences. From Hippocrates to Harvey, Aldershot 2000; Les Voies de la science grecque. Études sur la transmission des textes
} 
a transmission of this type always posed problems such as those of linguistic confusion, and of the search for equivalent terms. Without going into detail, we also know that in order to avoid any misunderstanding, the authors were led to adopt various strategies: they sought in particular to clarify the concepts through explanatory developments, and this often by means of the paraphrase, which is also seen in the case of our copy from Cracow.

\section{Summarizing in the margin and commenting below the text}

This type of reading is quite prevalent in our copy, in the case of the second and third book of the Ars medicinalis which generally deal with signs. A first annotation occurs at the place where Galen deals with the bodies which are presently unhealthy and about which it is necessary to establish a diagnosis, and thus to carry out the analysis of the signs. The annotations begin when Galen begins his demonstration and deals with a particular case, that of the unhealthy dispositions of the brain.

The annotator proceeds in two stages in his reading: first he points to the margin of the title of the section, as if he used it as a means of marking the passage, and then inscribes his comment below the main text (picture 2). The writing in the margin remains easily readable (we see clearly enough: 'signa [a] egritudinis cerebri' (unhealthy dispositions of the brain), 'signa [a] egritudinis cordis' (unhealthy heart), 'signa [a] egritudinis contra naturam [h] epatis' (unhealthy dispositions of the liver to evolve against nature), [signa [a] egritudinis] 'stchomachi' (unhealthy dispositions of the belly), 'pectoris' (unhealthy provisions of the thorax) 'duo [...] dolores' (two pains). On the other hand, the comments below the text are written in lowercase barely visible so that the annotation seems almost a straight line.

As regards these, we can sometimes read, albeit with difficulty, a few words of the comments placed at the margin, as, for example, in book III. The passage in the text is devoted to the visible signs of the good coction (picture 3). Here we read 'manifest quidem digestionis signis sanorum sunt' (signs that indicate a coction clearly visible are part of the healthy signs $)^{14}$. Under this passage, the annotator adds his commentary in which we can spot a few words: 'ut urina... alba... livida... frigoris... signa mortis. This shows that the annotator evidently assimilated, not without reason, the passage dealing with the visible signs of coction at uroscopy. We know that indeed in the functioning of the body, the ancients distinguished

de l'Antiquité au dix-neuvième siècle, ed. D. JaCquart, Genève 1997; D. JACQuart, C. ThomasSET, Lexique de la langue scientifique. Astrologie, mathématiques, médecine, Paris 1997; V. Nutton, The Changing Language of Medicine, 1450-1550, [in:] Vocabulary of Teaching and Research Between Middle Ages and Renaissance, ed. O. WeIjers, Turnhout 1995, p. 184-198.

${ }^{14}$ Galen, p. 343. 
four general coctions the results of which were visible at three stages of analysis: first in the excrement, then in the various humours and finally in the urine. The precise examination of the urine and its qualities (color, substance ('corpus urinae'), temperature, deposit, etc.) thus made it possible to diagnose the disease.

\section{Noting the essentials points}

The text of the commentator sometimes takes in our Articella obviously more amplitude. The notes appear in places where there is space (at the end of the book, on the back of the title page etc.). All these notes although they may seem relatively spontaneous (a note here, another there) nevertheless present in our treatise, for our great satisfaction, a real coherence of thematic order, namely the theme of the signs (picture 4).

\section{(Transcription)}

nigra ut cornu prendit viridis vel livida

Livida ut plumbum

alba ut aqua purrissima

Lactea ut [serum lactis]

Glauca ut cornu lucidum

Caropos ut vellus cameli

Pallida ut caro semicocta

Subpallida ea remissa colori

Citrinia ut color pomi citri[ni]

Subcitrinia ipsa remissa

Ruf[f]a ut aurum purrisimum orientale

[Sub]ruf[f] a ut aurum impurum

Rubra ut crocus orientalis

Subrubra ut crocus [h] ortulanus

Rubicunda ut sanguis purus

Subrubicunda ut sanguis aquosus

Caropos ut vinum nigrum [cf. inopos ut uinum nigrum]

Kianos ut purpura

Viridis ut caulis uiridis et signat adustionem

et signat mortificationem

et extinctionem caloris naturalis

indigestionem significant omnes iste quattuor

principium digestionis significant

sed non perfecta [mediatam digestionem]

perfectam digestionem [significant]

excessum digestionis

significant

In his note the annotator scrupulously grouped the colors of the urine. On the left (in red) is the catalog of colors which, to be clearly distinguished by the eye, the one who scrutinizes them, are compared either with materials (for example 'livida ut plumbum, pale like a lead) or with fruits (e.g. 'citrinia ut color pomi citri', yellow as a lemon) or liquids (e.g. 'rubicunda ut sanguis purus', red as pure blood). 
Right from time to time, there is a commentary that frames with small parentheses of the chosen colors and explains what this or that color means: some therefore mean perfect digestion ('perfect digestion'), others rather a imperfect digestion ('sed non perfecte'), others excess digestion ('excessum digestionis') or even heartburn ('ista signat adustionem') ${ }^{15}$.

Note that this list of eighteen colors arranged in columns follows the canonical colors that are usually found systematized in the wheel of urine ${ }^{16}$, a popular device used for diagnostic sometimes found in treatises of medicine ${ }^{17}$. Note also that the color comparisons we find in our list are the same as in other such wheels. And as the edition in question does not feature a wheel of urine (despite the presence of Theophile Protospatharios urine tract, Carmina de urinarum iudiciis), our annotator has obviously scrupulously copied in one spot all the urine colors in order to make use of his personal list to diagnose the disease.

Without multiplying the examples, let us add that the question of the colors of the urine was one of the principal ones for our reader. Thus the following annotation (picture 5) testifies to the concern to note carefully any shade of color. Some colors of the previous list are here completed: for example (center of the photo) 'lacteus ut serum lacti, ut aqua clara', other colors are however added as (bottom of the photo): 'inopos ut color epatis and ut uinum nigrum'; 'Albus is crystalline'18. All annotations remain grouped and are linked by small parentheses. This organization gives them the character of notes.

In ancient medicine, the color of the urine does not only indicate the disease, but it also characterizes each humoral type. Recall the canon: 'a sanguine-urina rubea; a colera-urina colore nimium citrinium; melancolia-glaucum; a flegmaalbum. Also, during urine analysis, apart from the color, the physician had to take into account the season of the year, the region, the age and the sex of the patient ${ }^{19}$.

\footnotetext{
${ }^{15}$ Cf. S. Zaun, H. Geisler, Die Harnfarbbezeichnungen im Fasciculus medicinae und ihre italienischen und spanischen Übersetzungen, [in:] Farbe im Mittelalter. Materialität, Medialität, Semantik, ed. I. Bennewitz, A. Schindler, Berlin 2011, p. 974.

${ }^{16}$ Examples of these are the wheels found in U. PINDER, Epifanie medicorum, Nürnberg: Friedrich Peypus for Ulrich Pinder, 1506, $\mathrm{f}^{\circ} 5 \mathrm{r}^{\circ}-5 \mathrm{v}^{\circ}$ or in J. DE Ketam, Fasciculus medicine; praxis tam chirurgis quam etiam physicis maxime necessaria, Venetiae: Joannem Gregorii de Gregoriis fratres, $1522, \mathrm{f}^{\circ} \mathrm{v}^{\circ}$. ${ }^{17}$ For the history of the transmission of the important treatments of urine (the Peri ouron of Theophile Protospatharios and the Liber uranarum of Isaac Israeli) we refer to L. Moulinier-Brogi, Uroscopie au Moyen-Âge. Lire dans un verre la nature de l'homme, Paris 2012, p. 54-55. On the colour techniques of this kind of works see S. Kusukawa, Picturing the Book of Nature. Image, Text, and Argument in Sixteenth-Century Human Anatomy and Medical Botany, Chicago-London 2012, p. 79-80. ${ }^{18} \mathrm{On}$ the enrichment of colors in uroscopy see L. MoulinIER-BRogi, L'uroscopie en vulgaire dans loccident médiéval: un tour d'horizon, [in:] Science translated. Latin and Vernacular translations of Scientific Treatises in Medieval Europe, ed. M. Goyens, P. De Leemans, A. Smets, Leuven 2008, p. 237-239.

${ }^{19}$ Cf. Actuari Johannis Zachariae filiI, Graeciae Medici principis De urinis, Trajecti ad Rhenum: ex officina Gysberti a Zyll, Bibliopolae, 1670, p. 58-61.
} 
Similarly, the correspondence between humours and moments of the day and the night is apparent in the following annotation, which tends to systematize the predominance of moods according to the hours of the day and those of the night (picture 6). Thus, the predominance of phlegm is: 'ad prima hora usquam ad sextam', that of melancholy 'a sexta usquam ad duodecimam', that of blood 'a duodecima usquam ad 18 [decimam octava]', that of anger finally 'decima octava usquam ad 1 [primam horam]'. Here the day ( 24 hours) is divided into four groups of six hours, each sixteen corresponding to a humoral type, which can not fail to surprise. Because this division of time, which starts at 1 o'clock and finishes at 6 o'clock, then lasts 6 hours and finishes at noon, etc., is out of step with the one sanctioned in the tradition, in Vindician, for example, which divides well the day and the night in six-hour sequences, but starting three hours earlier - or later: at 9 o'clock in the morning, at 3 oclock in the afternoon, and so on. It is also this division that is repeated in the verses 'Horae humorum', widely propagated later by Flos medicinae Scholae Salerni:
A nona noctis donec sit tertia lucis
Est dominans sanguis; sexque incurrentibus horis
Est dominans cholera, dum lucis nona sit hora; post niger humor adest, donc sit terita noctis; post hoc flegma, donec sit nona quietis ${ }^{20}$.

The concern to correctly diagnose and read the signs (the urine and its colors) is also evident in the following annotation (picture 7) concerning the correspondence between the mood and the type of pulse: this is how the pulse 'longus et latus' is specific to 'sanguis'; 'longus et strictus' characterizes anger; 'curtus et latus' refers to phlegm; 'curtus et strictus', finally, is related to the melancholic.

\section{Drawing to better remember}

All these correspondences framed in parentheses, arranged in groups, bring us in our Venetian copy to a fourth type of scholarly annotation: the mnemonic schema. Take the case of the drawing on the cover of the volume (picture 8). This diagram makes us attend a personal moment of our annotator who applies to assimilate well his course of physiology. This mnemonic figure sketched in speed during of after reading, can have no other purpose here than to help the one who made it to retain the quaternary theory with its five levels of correspondence (seasons of the year, element, wind, humours, age of life) or if one wants, with its five galenic tetrads.

\footnotetext{
${ }^{20}$ Flos medicinae Scholae Salerni. Comprenant les travaux inédits de M. Maudry de Balzac, ${ }^{2}$ Naples 1859, p. 49.
} 
This theory, as we know it, formed the basis of ancient medicine, and the first traces of it are already present in the Corpus Hippocraticum, in the treatise entitled The Nature of Man composed by Polybius, son-in-law of Hippocrates ${ }^{21}$. Without going into detail - we refer to the many works of Jacques Jouanna - we will simply recall that it is to Galen that the medical tradition attributes the glory of having brought to light the Quaternary theory, as it was inherited from Hippocrates as well as of his predecessors, Aristotle, Alkmaion of Crotone, Empedocles. Thanks to this work of systematization, Galen is known in the history of medicine as the father of 'tetrads', that is to say, the coordinate system based on the four elements ${ }^{22}$. After him, the Quaternary system underwent an increasingly complex development by the integration of new elements by late Greek medicine, the medieval West and the Byzantine era ${ }^{23}$. So that in the sixteenth century, by simplifying things a little, the tetrads appeared in their more or less stable form ${ }^{24}$. In the course of time new elements have been added to these tetrads, elements referring to the four main winds, the four apostles, the four planets, the zodiac signs, the four moments of the day, the four musical scales as well as the four regions of the human body, which is not small ${ }^{25}$.

The number of additional components to be retained to control the humoral theory having increased considerably, one can not doubt that after a certain time it had become difficult to memorize all the correspondences between elements, seasons, ages etc. It was then that various types of methodical diagrams in various forms, linear or circular, appeared, designed to facilitate the memorization of the multiple correspondences between the macrocosm (the universe) and the micro$\operatorname{cosm}(\operatorname{man})^{26}$. Examples of these aids to memory are multiple ${ }^{27}$. Among the known

\footnotetext{
${ }^{21}$ We refer to the complex subject of the transmission of the theory of moods through the Pseudo-Galenic treatises to J. Jounnna, Un pseudo-Galen inédit: Le pronostic sur l'homme. Contribution à l'histoire de la théorie quaternaire dans la médecine grecque tardive: l'insertion des quatre vents, [in:] Troika. Parcours antiques, Mélanges offerts à Michel Woronoff, vol. I, ed. S. David, E. Geny, Besançon 2007, p. 302-322; IDEM, Le Pseudo-Jean Damascène, [in:] Les Pères de l'Église face à la science médicale de leur temps, ed. V. Boudon-Millot, B. Pouderon, Paris 2005, p. 1-27.

${ }^{22}$ A. BednarCzyK, Medycyna i filozofia w starożytności, Warszawa 1999, p. 102-128.

${ }^{23}$ Let us note here, as J. Jouanna emphasizes, the importance of two treatises of Pseudo-Galen (Le prognostic sur l'homme and les Humeurs) and the Lettre à Pentadius of Vindician (see J. Jounnna, Un pseudo-Galen inédit..., p. 303).

${ }^{24} \mathrm{Cf}$. also the diagram at E. SCHÖNER, Das Viererchema in der antiken Humoralpathologie, Wiesbaden 1964, p. 64.

${ }^{25}$ On the fortune of the quaternary schema cf. L. DesJardins, Le corps parlant. Savoirs et représentation des passions au XVII siècle, Paris-Québec 2001, p. 45-48.

${ }^{26}$ G. Couton, Écritures codées, Essais sur l'allégorie au XVII siècle, Paris 1990, p. 170. Cf. also M. Carruthers, Machina memorialis. Méditation, rhétorique et fabrication des images au Moyen Âge, trans. F. Durand-Bogaert, Paris 2002, p. 51-52.

${ }^{27} \mathrm{Cf}$. L. Bolzoni, La chambre de la mémoire. Modèles littéraires et iconographiques à l'âge de l'imprimerie, trans. M.-F. Merger, Genève 2005, p. 57-136; R. Klibansky, E. Panofsky, F. Saxl, Saturne et la mélancolie, Études historiques et philosophiques. Nature, religion, médecine et arts, trans. F. DuRAND-BogaerT, L. Évrard, Paris 1989, p. 481, 514-515.
} 
diagrams that have already been the subject of commentary, let us recall that of Isidore of Seville who in the 'wheels' present in his De natura rerum, synthesizes the correspondences between the four qualities (hot and cold, dry and wet, combined two by two), the four elements, the four climates, the four seasons, the four moods and the four temperaments, and the four ages of life $\mathrm{e}^{28}$. Let us also mention the medico-astrological figures presented by Ernest Wickersheimer in "Janus"29, the emblems of Barthélemy Anneau ${ }^{30}$ and those of Johanes Sambucus ${ }^{31}$, the mnemonic engraving in the Quinta Essentia, a work by the alchemist Leonhard Thurneysser ${ }^{32}$, not forgetting the allegory of the four temperaments in the Iconology of Caesare Ripa ${ }^{33}$ and, finnaly, in the medical emblems of Louis de Caseneuve $^{34}$.

Our diagram reads from top to bottom going towards the center. On the first level are the four seasons of the year (uer, estas, hiems, autumnus), the second level, the four elements (aër, ignis, terra, aqua), the third level the four winds (Euros, Subsulanus, Boreas, Zephyrus). Then come, on the fourth level, the moods (sanguis, colera, melancolia, phlegma), and in the fifth, the four ages of human life (adolestentia, iuventus, senectus, senium). This diagram has at first sight nothing original, as it follows the consensus rerum that one meets since antiquity and thereafter in the verses of the Schola Medica Salernitana ${ }^{35}$ : that is to aer, sanguis, pueritia, uer / ignis, aestas, cholera, juuentus / Autumnus, terra, melancholia, senectus / Decrepitus, hyems, aqua, flegma. On the other hand, the addition of the four winds - three of which were already considered to be main in the Homeric period (Boreas, Euros, Zephyr) - to correspond to moods of the four humours deserves our attention. Indeed, looked at it closely, the shape given to the diagram is curious. Whether it is the result of errors made by the annotator, the winds do not correspond to the canon of the winds as we know it from the Pseudo-Galen treatise ${ }^{36}$.

\footnotetext{
${ }^{28}$ La médecine médiévale à travers les manuscrits de la Bibliothèque Nationale. Exposition Bibliothèque nationale, Paris, 31 août - 5 octobre 1982, praef. A. Gourdon, J.-C. Sournia, Paris 1982, p. 39. See also B. ОвRIsт, Le diagramme isidorien des saisons, son contenu physique et les représentations figuratives, MEFR.MÂ 108, 1, 1996, p. 95-164.

${ }^{29}$ E. Wickersheimer, Figures médico-astrologiques des IX $X^{e}, X^{e}$ et XI $I^{e}$ siècles, Jan 19, 1914, p. 157-177.

${ }^{30} \mathrm{~B}$. ANNEAU, Imagination poétique, Lyon: Macé Bonhomme, $1552, \mathrm{f}^{\circ} \mathrm{C} 2 \mathrm{v}^{\circ}$.

${ }^{31}$ J. Sambucus, Les emblèmes, Antverp: Christophe Plantin, 1567, $\mathrm{f}^{\circ} \mathrm{H} 4 \mathrm{r}^{\circ}$.

${ }^{32}$ L. Thurneysser, Quinta essentia, Leipzig: [s. 1.], 1574, p. 153.

${ }^{33}$ C. RIPA, Iconologia, Roma: appresso Lepido Facii, 1603, p. 75, 77, 78, 79.

${ }^{34}$ L. Casanova, Hieroglyphicorum et medicorum emblematum Dodekakroynos, [in:] I.P. Valerianis Hieroglyphica, Lugduni: apud Paulum Frellon, 1626, p. 31, 40, 63, 70.

${ }^{35}$ Flos medicinae Scholae Salerni..., p. 50: Consona sunt aer, sanguis, pueritia, uerque; conueniunt ignis, aestats, choleraque, juuentus; Autumnus, terra, melancholia, senectus; Decrepitus uel hyems, aqua, flegmaque sociantur.

${ }^{36}$ For more details we refer to the article by Jacques Jouanna where the author has already traced the fascinating history of variations on the winds, a history which remains rather obscure. See J. JouANNA, Un pseudo-Galen inédit..., p. 319.
} 
It should also be added that beside the diagrams there are also, in the Venetian copy, annotations which resemble a list of abbreviations for apothecary measurements, that is to say manipulates, scruple, drachma, book, ounce, grain, etc.

Who did this copy belong to and who had so richly annotated it? Let's stop for a moment on the source. On the title page we see several signatures (picture 9). First, that of its first owner with a name that is difficult to identify ('sum mgri... Symon S...) but which in all probability belonged to a printer family in Cracow. We meet the signature of a second owner and it is to him that we should attribute the annotations we have presented. That owner was Marcin de Urzedowo (born in 1500 in Urzedow Lubelski, died in 1573 in Sandomierz), botanist, pharmacist, doctor, priest, and author of the first herbarium in Polish (Cracow, 1595). In 1517 he began his studies at the Jagiellonian University (Artes Liberales), in 1521 he received his license (licentia docendi), in 1525 became the title of magister. In 1529 he was appointed superior of the Collegium Minor and in 1533 dean of the faculty. Marcin de Urzedowo continued his medical studies in 1534 in Padua, where in 1538 he received a doctorate in medicine. He travelled to Hungary and Switzerland. He became the regular doctor of Jean Amor Tarnowski of Leliwa, one of the first hetmans ${ }^{37}$ in the Polish army, who modernized, among other things, government-funded field hospitals, military quarter services and sappers. We also know that the copy in question belonged by successive donations to the Carmelite convent in Lvov, then to those of Cracow.

\section{Amending with a view to a future edition of the text}

We will now consider briefly the copy of the Latin edition of Galen (Venice, Iuntae, 1531), also belonging to the library, because it allows us to document a last type of reader annotations intended to amend the text in order to a subsequent edition.

The volume is distinguished by a double provenance: first, Hieronus Mazzarini - (owner since 1568) and second, the family of Nayman, rectors of the Jagiellonian University (seventeenth century). However, at the end of the volume, we discover a fragment, written in the same hand as the annotations encountered in the whole of the copy, below which figure (a rare occurrence!), a very precise date: January 29,1543 at two o'clock in the night ('1543 die ianuari hora secunda noctis') (picture 10). The annotations are therefore, from an annotator prior to the first owner (Hieronimus Mazzarini) and thus fit within the period considered.

The name of Galen is the subject of a handwritten mention on three occasions in the copy: at the beginning where we can distinguish (Galeni methodi medendi cap. 6), in the middle (Gal. in Tegni); and at the bottom (Gal. in 8 usu [partium]). But it is the accumulation of annotations that we encounter in $D e$ tumoribus which is quite astonishing (picture 11). The annotator does the work

\footnotetext{
${ }^{37}$ A political title from Central and Eastern Europe historically assigned to military commanders.
} 
of a real philologist; he comments, spots faults, proposes modifications, refers to other treatises. These annotations can be divided between two groups: purely graphic interventions and philological interventions. The first group includes all the changes where the annotator divides the main text into chapters ('caput 8' / 'caput 9'), signals where to insert text, marks with small square brackets words to insert ('sic', 'uidet'); marks the names of tumors in margin ('Oedma', 'Scyrrus', 'echymomata') so that they serve as easy reference ${ }^{38}$. To the second group, the "philologist one", we assign places where the annotator crosses a letter in the printed text and propose another one instead (for example p. 220 line 6 'pituitae' replaced by 'pituita'; line 6 'altera' replaced by 'alterum'), or places where he strikes out an entire word and replace it with another word (for example p. 220, line 19 'ubi eontunduntur' replaced by 'ubi comprimitur'; 'enim' replaced by 'etiam', or again when he refers to other books that deal with the same issue, for example at the bottom of the page 'Ad Glauconem...). The question of the correctness of these philological interventions remains open and awaits a separate study.

In conclusion, the pages of the copies preserved in the Cracow Library of Carmelites, of Latin editions of Galen's works, which we have just analyzed, retain traces of the scholarly reading of those who possessed and consulted them. Whether they were doctors, botanists, apothecaries, or in one case at least, editor / proof-reader, the hand-written inscriptions all testify to a conception of reading as study and of the annotation of the works as an instrument of an appropriation of Galen's thought. Marked by time and by their owners, these volumes constitute an excellent object of research. On the one hand and from the perspective of the history of the book, these copies bear witness to the circulation of Galen Latin editions in the sixteenth century far beyond the borders of Western Europe. On the other hand and from the perspective of the history of ideas, the annotations, examples of which we presented some types, reveal the spirit in which Galen was understood at the time and are a valuable document on the reception of the corpus galenicum on the threshold of modernity.

Translated by Justyna Sowińska

\footnotetext{
${ }^{38} \mathrm{Cf}$. for example the translation of GALIEN, Des tumeurs contre nature, Lyon: Etienne Dolet, 1540, p. $7-8$.
} 


\section{Bibliography}

\section{Primary Sources}

Actuari Johannis Zachariae filiI, Graeciae Medici principis De urinis, Trajecti ad Rhenum: ex officina Gysberti a Zyll, Bibliopolae, 1670.

Anneau B., Imagination poétique, Lyon: Macé Bonhomme, 1552, f ${ }^{\circ} \mathrm{C} 2 \mathrm{v}^{\circ}$.

Articella, Venetiis: per Petrum Bergomensem de Quarengiis, 1507.

Carmina de urinarum iudicijs: edita ab excellentissimo domino magistro Egidio cum expositione et commento magistri Gentilis de fulgineo noviter castigatis et pluribus in locis emendatis per magistrum Avenantium de camerino artium et medicine professorem, Lugduni: per Franciscum Fradin, 1505.

CaSanova L., Hieroglyphicorum et medicorum emblematum Dodekakroynos, [in:] I.P. Valerianis Hieroglyphica, Lugduni: apud Paulum Frellon, 1626.

Claudii Galeni Pergameni, medicorum, post Hippocratem principis, haec opera, vol. V, Venetiis: in aedibus Lucaeantonii Iuntae Florentini, 1531.

De Keтам J., Fasciculus medicine; praxis tam chirurgis quam etiam physicis maxime necessaria, Venetiae: Joannem Gregorii de Gregoriis fratres, 1522.

[Galen] Ars medicinalis, [in:] Hippocrates, Hippocratis ac Galeni libri aliquot, ed. F. Rabelais, Lyons: s. Gryphius, 1532-1533. Translation: Galen, vol. II, Exhortation à la médecine. Art médical, trans. et ed. V. Boudon, Paris 2000.

Galien, Des tumeurs contre nature, Lyon: Etienne Dolet, 1540.

Pinder U., Epifanie medicorum, Nürnberg: Friedrich Peypus for Ulrich Pinder, 1506.

Ripa C., Iconologia, Roma: appresso Lepido Facii, 1603.

Sambucus J., Les emblèmes, Antverp: Christophe Plantin, 1567, $\mathrm{f}^{\circ} \mathrm{H} 4 \mathrm{r}^{\circ}$.

Thurneysser L., Quinta essentia, Leipzig: [s. 1.], 1574.

\section{Secondary Literature}

Bednarczy A., Medycyna i filozofia w starożytności, Warszawa 1999.

Bolzoni L., La chambre de la mémoire. Modèles littéraires et iconographiques à l'âge de l'imprimerie, trans. M.-F. Merger, Genève 2005.

Boudon V., 'Ars medica' de Galien, Paris 2000.

Boudon V., La translation antiqua de l'Art médical de Galien, [in:] Storia e ecdotica dei testi medici greci, ed. A. Garzyna, J. Jouanna, Napoli 1995, p. 43-55.

Carruthers M., Machina memorialis. Méditation, rhétorique et fabrication des images au Moyen Âge, trans. F. Durand-Bogaert, Paris 2002.

Chatelain J.-M., Humanisme et culture de la note, "Revue de la Bibliothèque Nationale de France" 2, 1999, p. 26-36.

Couton G., Écritures codées, Essais sur l'allégorie au XVII siècle, Paris 1990.

DesJaRdins L., Le corps parlant. Savoirs et représentation des passions au XVII siècle, Paris-Québec 2001.

Durling J.R., A Chronological Census of Renaissance Editions and Translations of Galen, "Journal of the Warburg and Courtauld Institutes" 24, 3/4, 1961, p. 230-305. 
Flos medicinae Scholae Salerni. Comprenant les travaux inédits de M. Maudry de Balzac, ${ }^{2}$ Naples 1859.

Fortuna S., Galeno a Sarnano: le Giuntine del 1531 e del 1533, "Italia medioevale e umanistica" 37, 1994, p. 241-250.

Fortuna S., The Latin Editions of Galen's 'Opera omnia' (1490-1625) and their Prefaces, "Early Science and Medicine" 17, 2012, p. 391-412.

French R., Ancients and Moderns in the Medical Sciences. From Hippocrates to Harvey, Aldershot 2000.

Jacquart D., Thomasset C., Lexique de la langue scientifique. Astrologie, mathématiques, médecine, Paris 1997.

Jouanna J., Un pseudo-Galen inédit: Le pronostic sur l'homme. Contribution à l'histoire de la théorie quaternaire dans la médecine grecque tardive: l'insertion des quatre vents, [in:] Troika. Parcours antiques, Mélanges offerts à Michel Woronoff, vol. I, ed. S. DAvid, E. Geny, Besançon 2007, p. 302-322.

Jouanna J., Le Pseudo-Jean Damascène, [in:] Les Pères de l'Église face à la science médicale de leur temps, ed. V. Boudon-Millot, B. Pouderon, Paris 2005, p. 1-27.

Klibansky R., Panofsky E., Saxl F., Saturne et la mélancolie, Études historiques et philosophiques. Nature, religion, médecine et arts, trans. F. Durand-Bogaert, L. Évrard, Paris 1989.

KoźLuk M., SuŁecki S., Une petite perle de Cracovie: la bibliothèque médicale d'Anton Scherberger (1530-1581), "Histoire des sciences médicales" 46, 4, 2012, p. 441-452.

Kusukawa S., Picturing the Book of Nature. Image, Text, and Argument in Sixteenth-Century Human Anatomy and Medical Botany, Chicago-London 2012.

La médecine médiévale à travers les manuscrits de la Bibliothèque Nationale. Exposition Bibliothèque nationale, Paris, 31 août - 5 octobre 1982, praef. A. Gourdon, J.-C. Sournia, Paris 1982.

Moulinier-Brogi L., Uroscopie au Moyen-Âge. Lire dans un verre la nature de l'homme, Paris 2012.

Moulinier-Brogi L., L'uroscopie en vulgaire dans l'occident médiéval: un tour d'horizon, [in:] Science translated. Latin and Vernacular translations of Scientific Treatises in Medieval Europe, ed. M. Goyens, P. De Leemans, A. Smets, Leuven 2008, p. 221-241.

Nutton V., The Changing Language of Medicine, 1450-1550, [in:] Vocabulary of Teaching and Research Between Middle Ages and Renaissance, ed. O. Weijers, Turnhout 1995, p. 184-198.

OвRIsт B., Le diagramme isidorien des saisons, son contenu physique et les représentations figuratives, "Mélanges de l'École Française de Rome. Moyen âge et temps modernes" 108, 1, 1996, p. 95-164.

Palmieri N., Sur les traces d'une ancienne traduction latine de l'Ars medica, "Latomus" 56, 1977, p. 504-533.

SCHÖner E., Das Viererchema in der antiken Humoralpathologie, Wiesbaden 1964.

Les Voies de la science grecque. Études sur la transmission des textes de l'Antiquité au dix-neuvième siècle, ed. D. JACQUART, Genève 1997.

Wallis F., $13^{\text {th }}$ Century Commentaries on the Tegni: Bartholomaeus of Salerno and Others, [in:] L'Ars Medica (Tegni) de Galien. Lectures antiques et médiévales, ed. N. PAlmieri, Saint-Étienne 2008, p. $127-168$.

Wickersheimer E., Figures médico-astrologiques des IXe, $X^{e}$ et XI siècles, “Janus” 19, 1914, p. 157-177.

Zaun S., Geisler H., Die Harnfarbbezeichnungen im Fasciculus medicinae und ihre italienischen und spanischen Übersetzungen, [in:] Farbe im Mittelalter. Materialität, Medialität, Semantik, ed. I. Bennewitz, A. Schindler, Berlin 2011, p. 969-986. 


\begin{abstract}
Copies of early-printed books have been of interest to to-day's collectors and researchers not only for their material aspects (names of publishers and places of printing, fonts and composition, number of known copies etc.), but also because they bear signs of their often erratic history following their publication. The path followed by a particular copy of an early-printed book is reflected in its general state as an object (for instance the state of its binding), but also in its internal aspect. On the pages of a copy of an early-printed book, annotations, drawings doodles or graphics testify to the intimate relationship that its owners entertained with it.
\end{abstract}

To better understand how owners dealt with copies of the books they possessed, this paper examines the annotations found in copies of some books that belong to the Carmelite convent in Cracow. We hope to bring to the attention of scholars, copies of works of Galen housed in this library, and primarily to set a perspective on how books were read by cultured individuals of in the $16^{\text {th }}$ century period. To do so, we analyse copies of the 1507 Venice edition of the Articella and a copy of Latin edition of Galien (Iuntae, Venice, 1531). We attempt to identify the intellectual perspectives from which cultured readers approached such texts in the $16^{\text {th }}$ century.

Keywords: Galen editions, library of Carmelites in Cracow, scientific annotations, scholarly reading, classical medicine, marginal annotations, nomenclature.

Magdalena Koźluk

University of Łódź

Department of Romance Philology

ul. Pomorska 171/173

90-236 Łódź, Poland magdalena.kozluk@uni.lodz.pl 


\section{ILLUSTRATIONS}

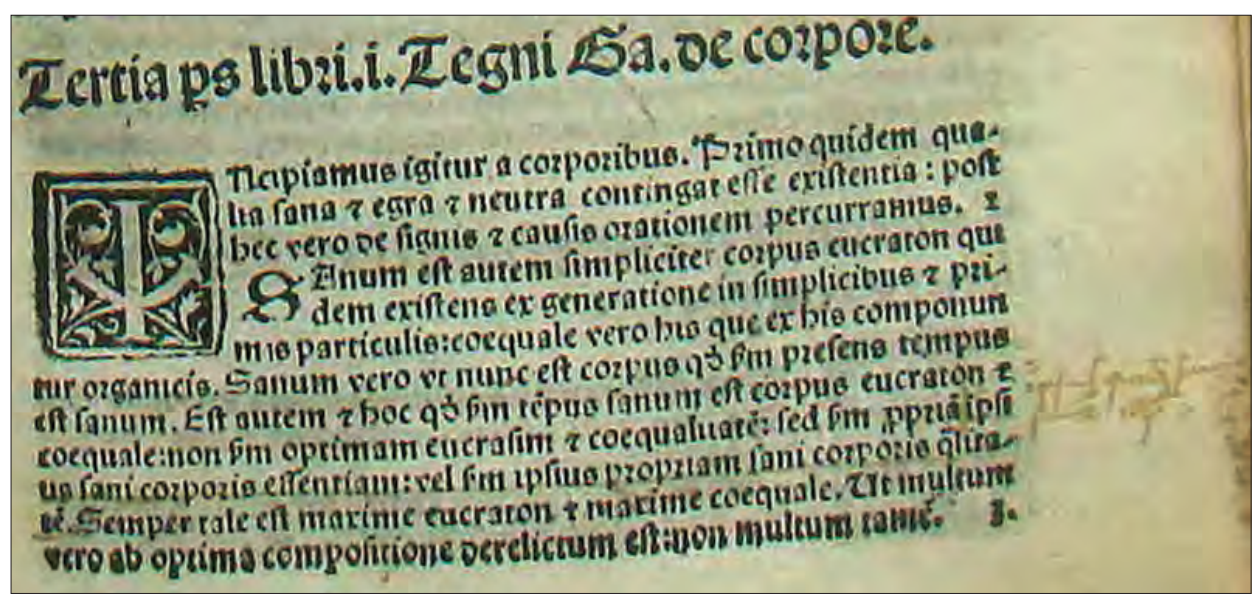

Fig. 1. Tertia $p$ [ar] s libri I. Tegni Ga.[leni] de corpore, [in:] Articella, Venetiis: per Petrum Bergomensem de Quarengiis, 1507, fo b $8 \mathrm{r}^{\circ}$

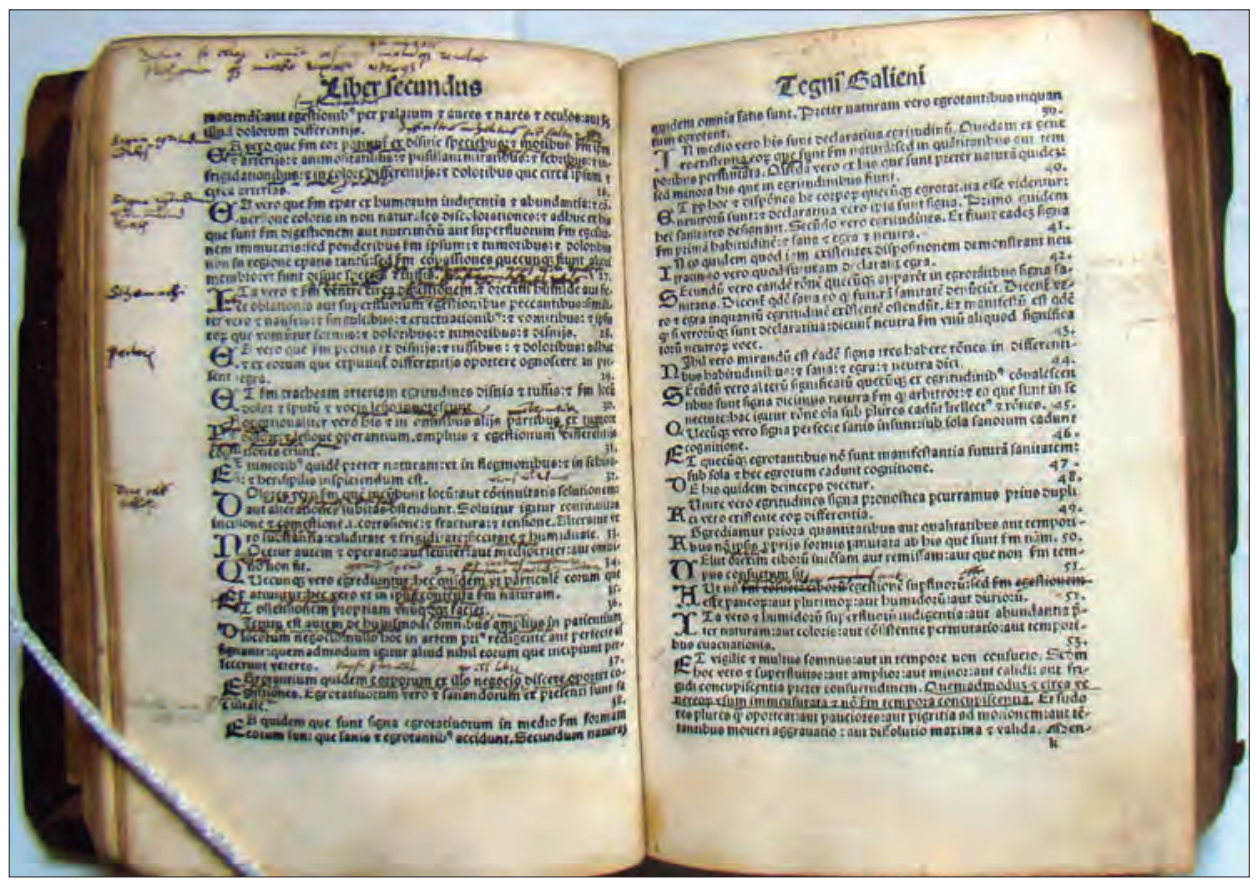

Fig. 2. Tertia $p$ [ar]s libri II. Tegni Ga.[leni] de corpore, [in:] Articella, Venetiis: per Petrum Bergomensem de Quarengiis, 1507, fo $\mathrm{k} 1 \mathrm{r}^{\circ}$ 


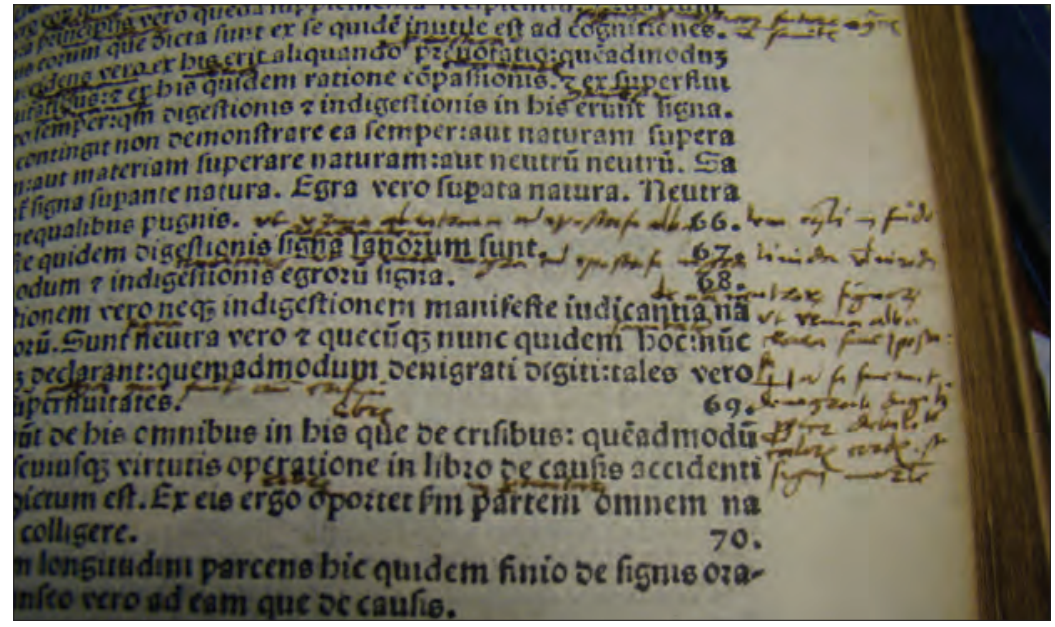

Fig. 3. Tertia $p$ [ar]s libri I. Tegni Ga.[leni] de corpore, [in:] Articella, Venetiis: per Petrum Bergomensem de Quarengiis, 1507, $\mathrm{f}^{\circ} \mathrm{k} 2 \mathrm{r}^{\circ}$

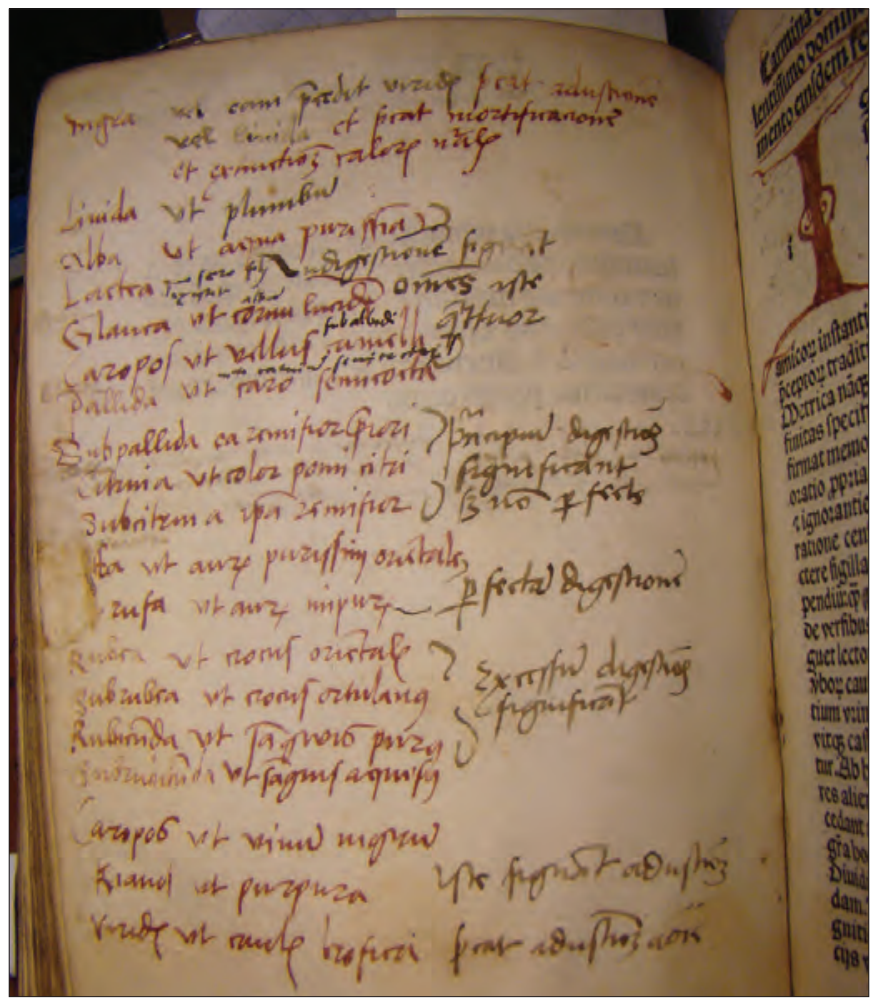

Fig. 4. Liber Theophili de urinis, [in:] Articella, Venetiis: per Petrum Bergomensem de Quarengiis, 1507 (cover recto) 


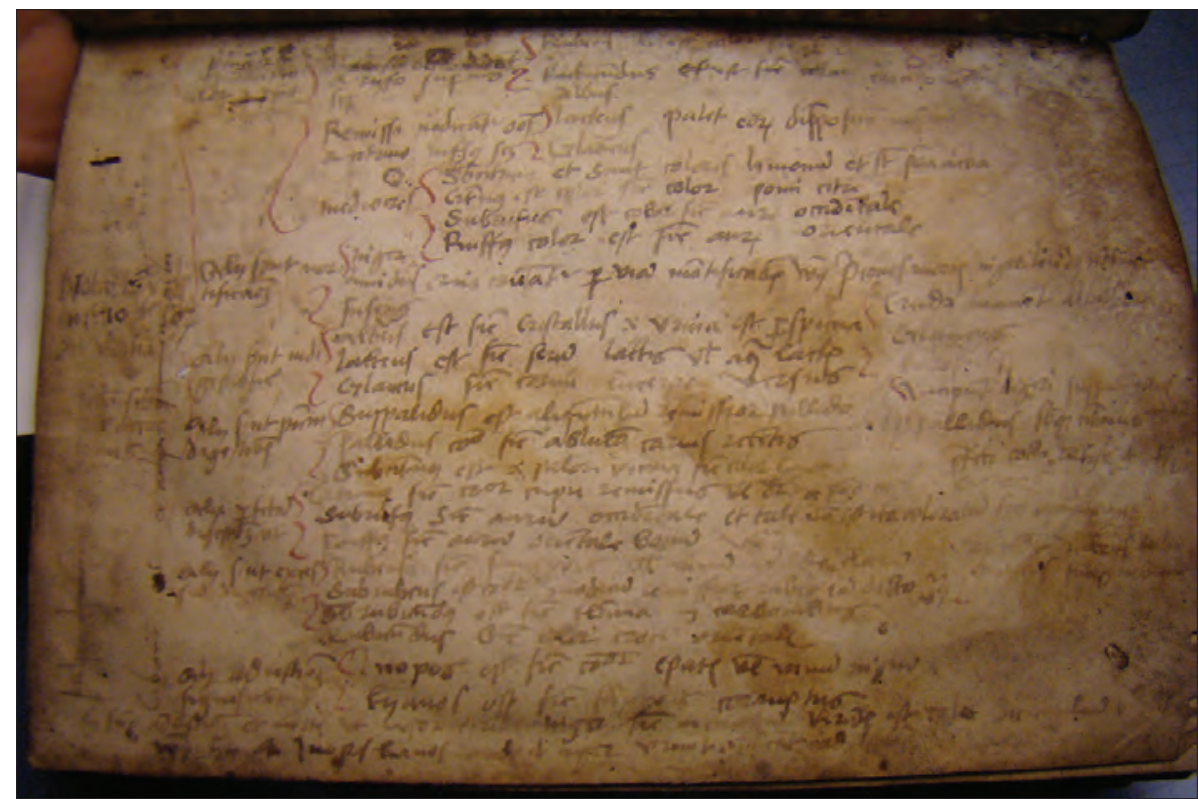

Fig. 5. Liber Theophili de urinis, [in:] Articella, Venetiis: per Petrum Bergomensem de Quarengiis, 1507 (cover recto)

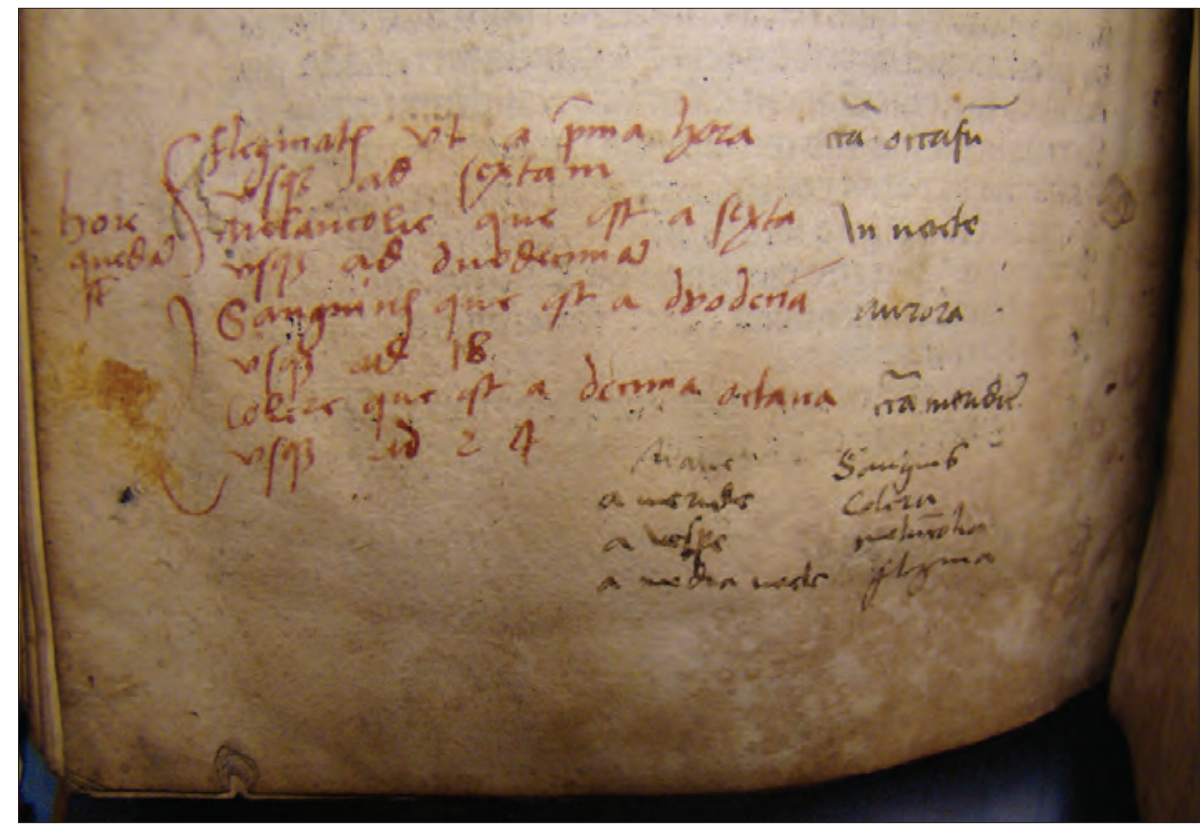

Fig. 6. Liber Theophili de urinis, [in:] Articella, Venetiis: per Petrum Bergomensem de Quarengiis, 1507 (cover recto) 


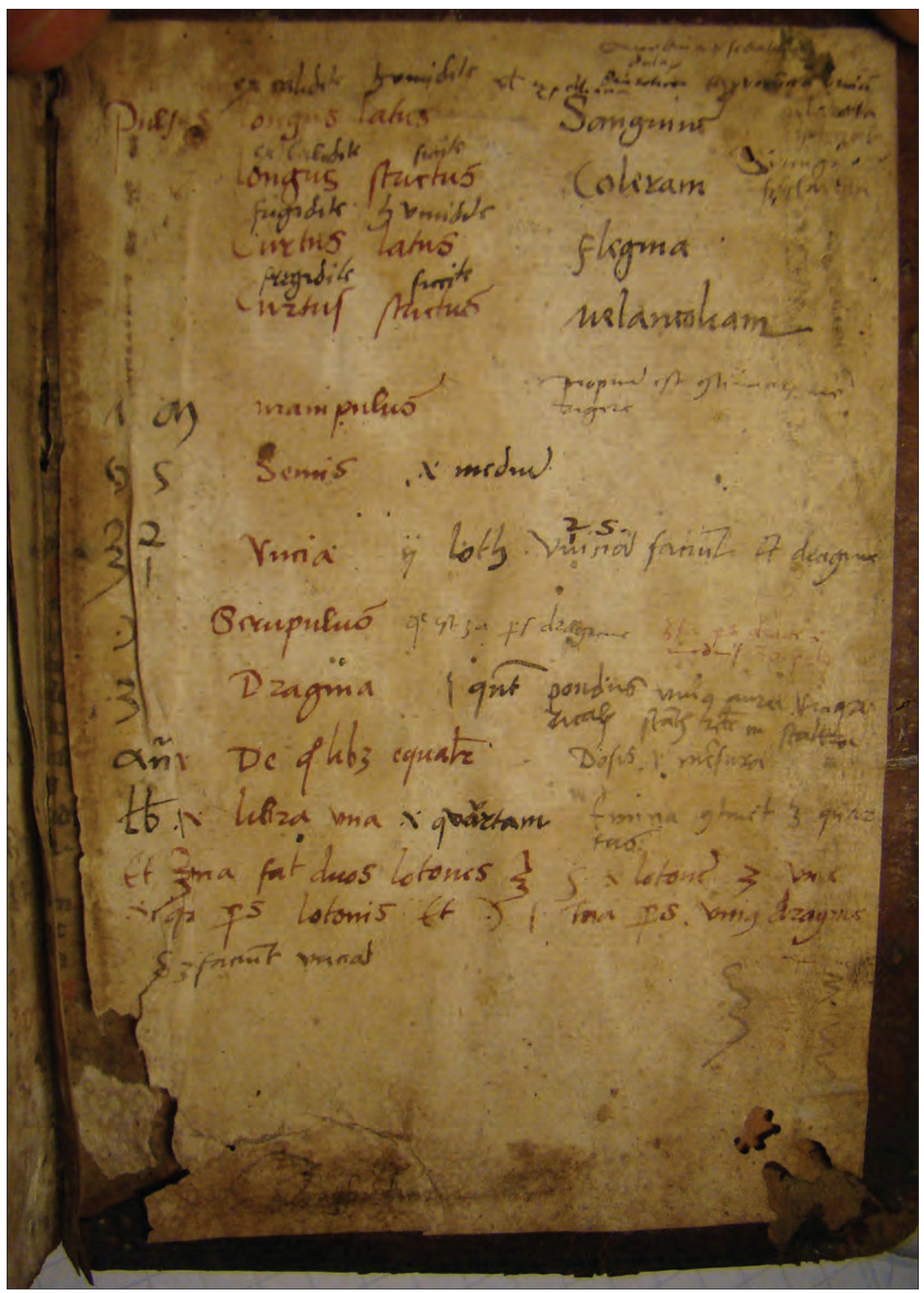

Fig. 7. Articella, Venetiis: per Petrum Bergomensem de Quarengiis, 1507 (cover recto) 


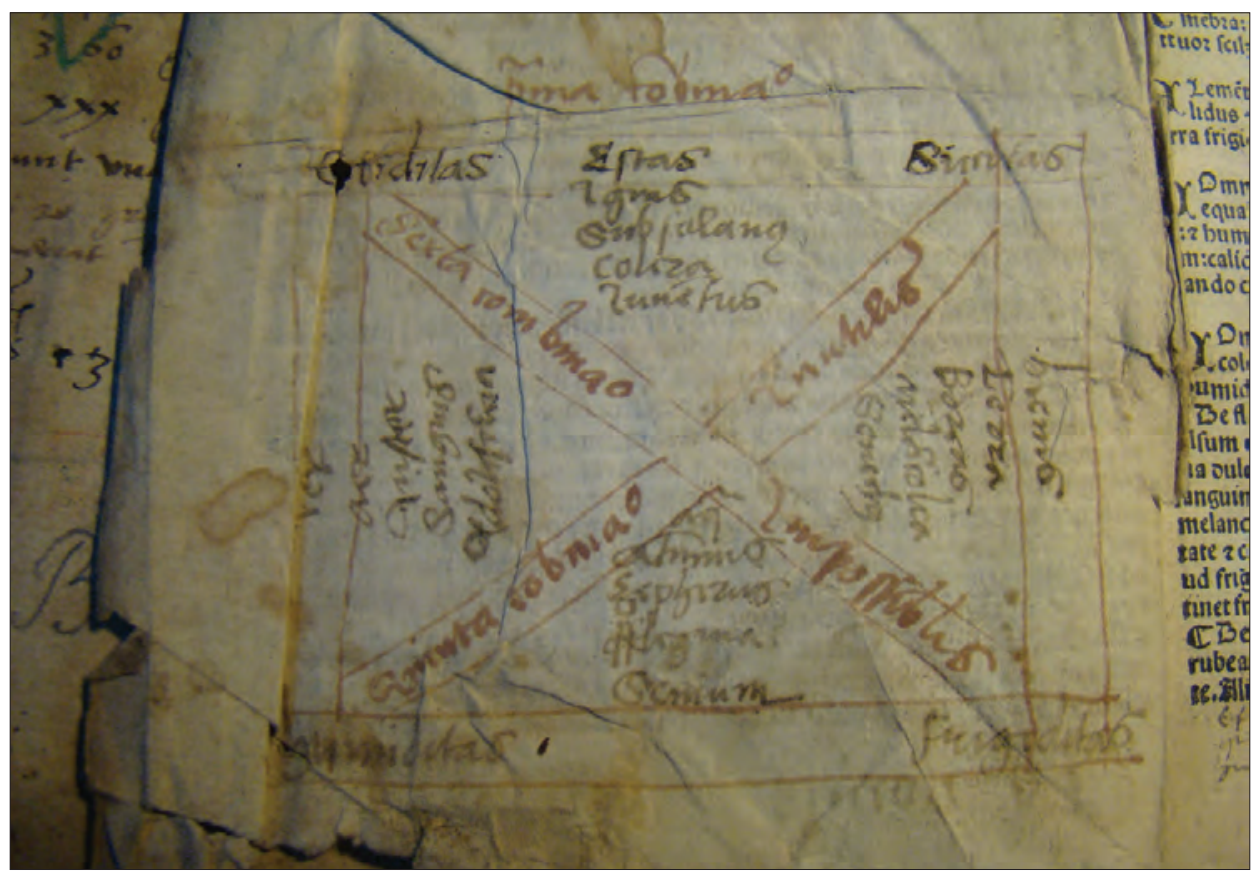

Fig. 8. Articella, Venetiis: per Petrum Bergomensem de Quarengiis, 1507 (cover recto)

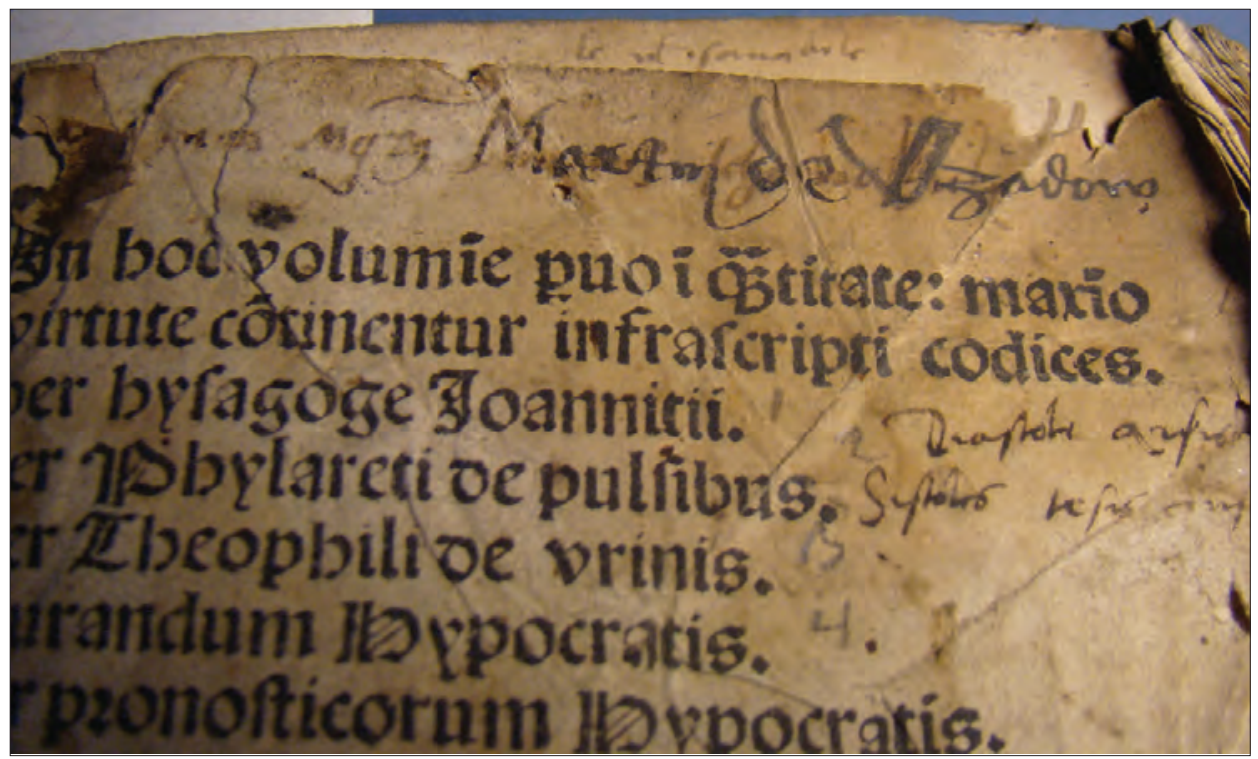

Fig. 9. Articella, Venetiis: per Petrum Bergomensem de Quarengiis, 1507 (title’s page) 


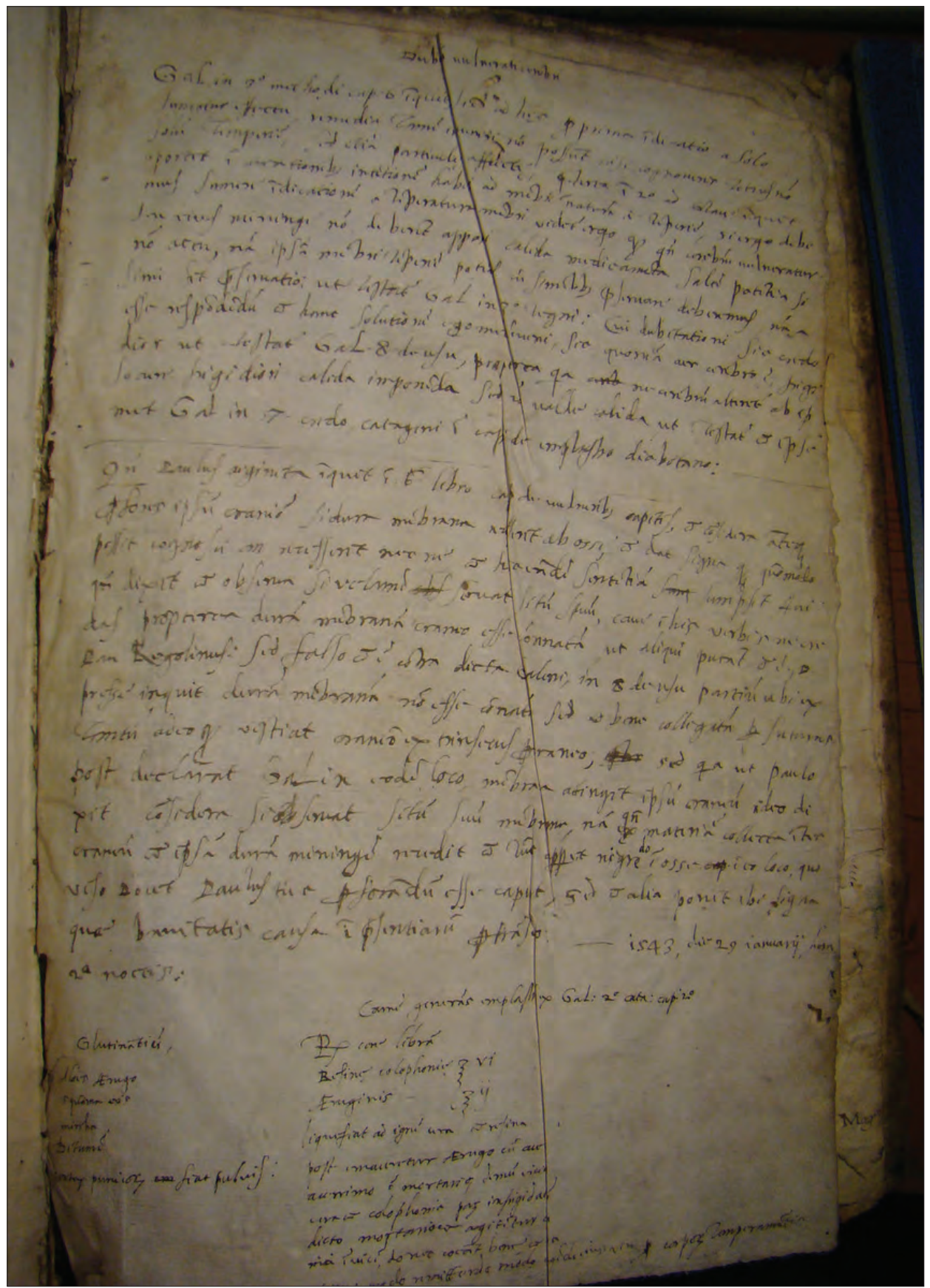

Fig. 10. Claudii Galeni Pergameni, medicorum, post Hippocratem principis, haec opera, vol. V, Venetiis: in aedibus Lucaeantonii Iuntae Florentini, 1531, (cover page) 


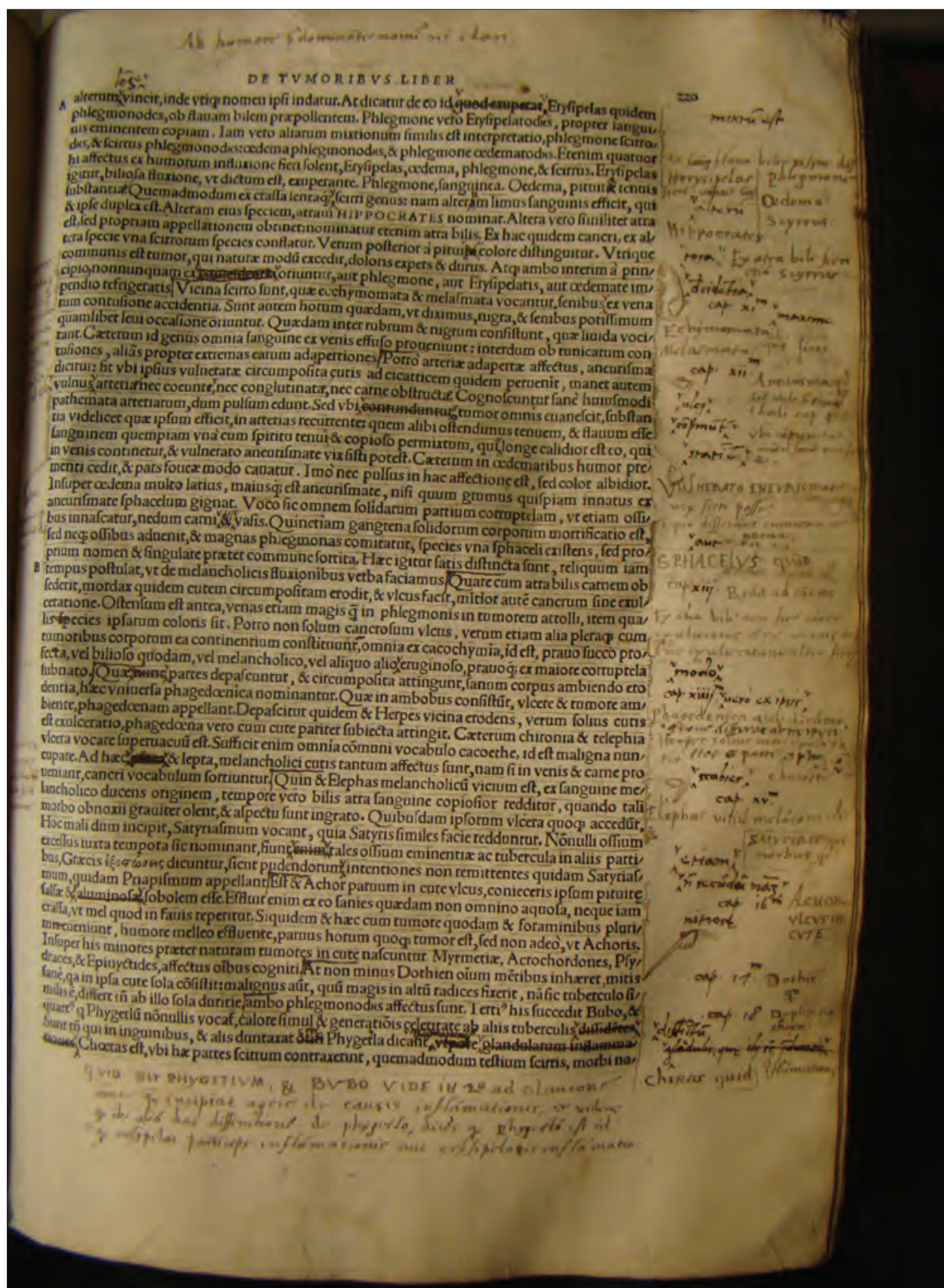

Fig. 11. Galenus, De Tumoribus liber, [in:] Claudii Galeni Pergameni, medicorum, post Hippocratem principis, haec opera, vol. V, Venetiis: in aedibus Lucaeantonii Iuntae Florentini, 1531 , p. 220 


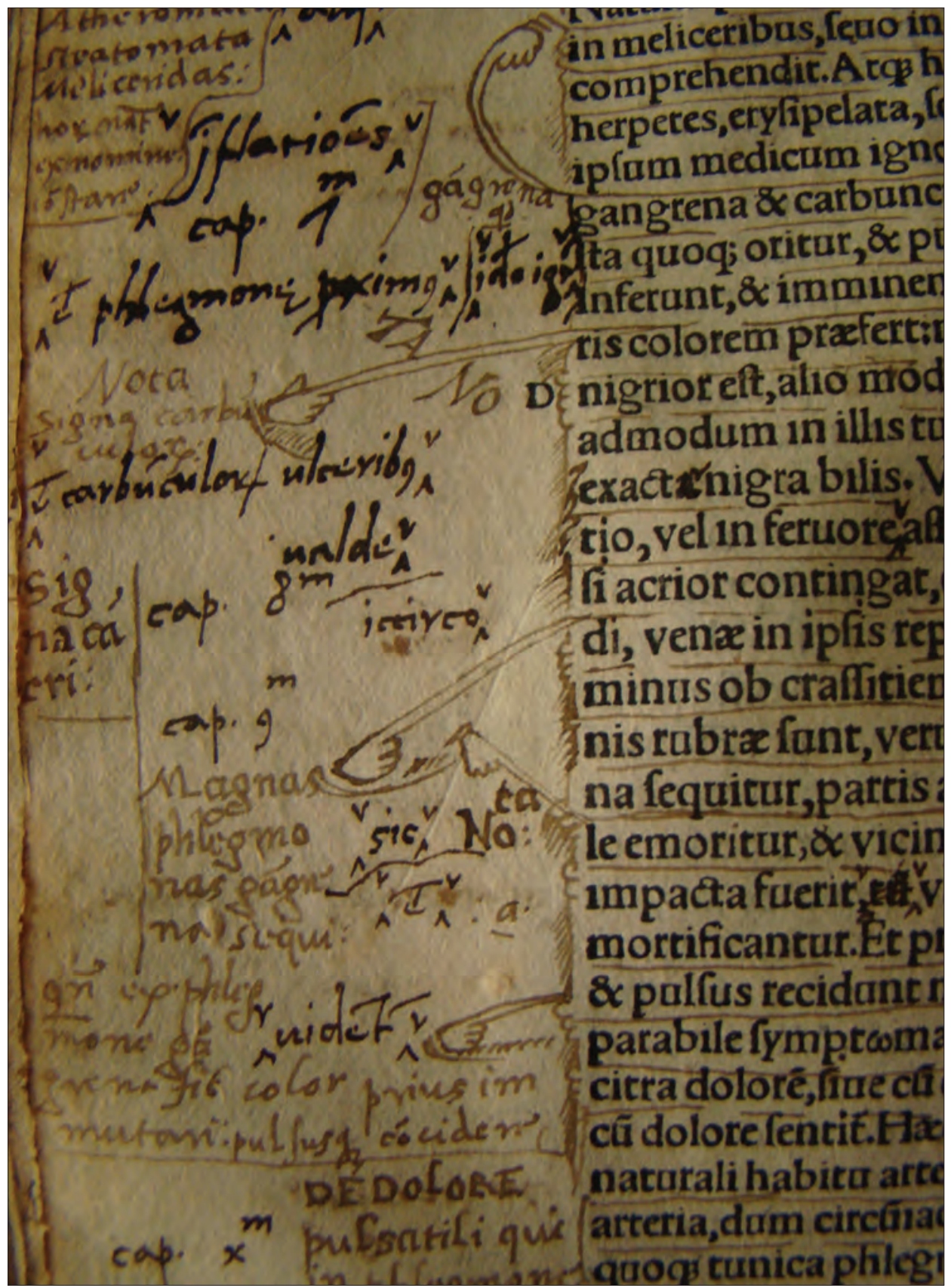

Fig. 11a. Galenus, De Tumoribus liber, [in:] Claudii Galeni Pergameni, medicorum, post Hippocratem principis, haec opera, vol. V, Venetiis: in aedibus Lucaeantonii Iuntae Florentini, 1531, p. 220 